\title{
Research on the Revitalization of Talents in the old Revolutionary Areas of Sichuan Province
}

\author{
Xiaomei Pu \\ Research center of Sichuan Old Revolutionary Areas Development, Sichuan University of Arts and Science, Dazhou, China \\ Email: 47872614@qq.com
}

How to cite this paper: $\mathrm{Pu}, \mathrm{X} . \mathrm{M}$. (2019) Research on the Revitalization of Talents in the Old Revolutionary Areas of Sichuan Province. Open Access Library Journal, 6: e5514.

https://doi.org/10.4236/oalib.1105514

Received: May 31, 2019

Accepted: June 25, 2019

Published: June 28, 2019

Copyright (C) 2019 by author(s) and Open Access Library Inc.

This work is licensed under the Creative

Commons Attribution International

License (CC BY 4.0).

http://creativecommons.org/licenses/by/4.0/

\begin{abstract}
The economic development of the old revolutionary areas in Sichuan Province is backward, especially in the rural areas. To solve this problem, it is necessary to implement the rural revitalization strategy. The biggest problem and key issue in implementing the rural revitalization strategy are the talent problem. This study analyzes the reasons for the lack of rural revitalization talents in the old revolutionary areas of Sichuan from the perspective of local talents and talents from other places, and puts forward corresponding countermeasures, which can provide certain ideas for solving the problem of revitalizing talents in the old revolutionary areas of Sichuan.
\end{abstract}

\section{Subject Areas}

Sociology

\section{Keywords}

Sichuan Old Revolutionary Areas, Rural Revitalization, Talents, Countermeasures

\section{Introduction}

General Secretary Xi Jinping emphasized that the implementation of the strategy of Rural Revitalization is a major decision-making arrangement which made at the Nineteenth National Congress of the Party, an important historical task to win the victory of building a well-off society and a socialist modern country in an all-round way, and a good way to promote the work of agriculture, countryside and farmers in the new era. Vitalizing rural talents is the key. Without people, it is meaningless to revitalize rural areas; without talents, it is impossible to revitalize rural areas.

However, there are few studies on the issue of rural rejuvenation of talents, 
mainly including the following aspects. Firstly, on the analysis of the reasons for the lack of talents in rural rejuvenation, Deng Lei (2019) [1] and others analyzed the reasons for the transfer of rural labor force in western minority areas from the aspects of economy, urbanization, urban-rural disparity and so on. Then, about the reasons for talent return, Liu Zuyun and Jiang Shu (2019) [2] analyzed the reasons why talent is willing to return from the aspects of traditional culture gene and realistic social situation. Thirdly, when talking about how to retain talents for rural revitalization, Zhang Hushan (2019) [3] and others believe that the attraction of talents should be strengthened through industrial development and perfect system. While, Ye Xingqing (2019) [4] and others think that we should increase the institutional supply of Rural Revitalization from the aspects of social security and the separation of the three rights of farmland to retain talents. Zhang Gang (2018) [5] and others believed that different countermeasures should be taken in rural people, urban people and leaders to really gather the popularity of the countryside. The above studies are helpful to solve the problem of talents in rural revitalization, but they have not systematically studied the current situation and causes of the lack of talents, even who are needed for rural revitalization, and what conditions are needed for the return of these different types of people. Therefore, it is necessary to make in-depth and systematic study on the talent problem of rural revitalization.

The old revolutionary area in Sichuan was a revolutionary base and guerrilla area created by the Communist Party of China in Sichuan during the Agrarian Revolutionary War, which made great sacrifices and contributions to the victory of the Chinese revolution and the establishment of New China. In order to inherit and carry forward the glorious tradition and dedication of the old revolutionary districts and support the development of various undertakings in the old revolutionary districts, the provincial government identified 81 cities and districts city as the old revolutionary areas in 2010, such as Qionglai (Sichuan government document No. 177, 2010). In 2011, the provincial government promulgated the Development Plan for the Old Revolutionary Areas in Sichuan Province during the 12th Five-Year Plan, which pointed out the direction for the development of the old revolutionary areas during the 12th Five-Year Plan period. Subsequently, the academic circles carried out research on this, mainly including culture, ecology, education, economy and so on. However, the problems faced by the old revolutionary areas in Sichuan are still very serious. Up to May 2019, there are still 15 state poverty counties in the old revolutionary areas of Sichuan, accounting for $45 \%$ of the total number of poverty-stricken counties at the national level in Sichuan Province, and 15 provincial poverty counties at, accounting for $42 \%$ of the total number of poverty-stricken counties at the provincial level in Sichuan. The fundamental problem of the old revolutionary areas in Sichuan is the economic problem, and the key is the rural economic problem. To solve the rural economic problems, we must implement the strategy of rural revitalization. The old revolutionary area in Sichuan is an important area for labor 
transfer. According to the sample survey of Baishuba Village, Yongning Town, Wanyuan City, and Shahe Village, Qilong Town, Kaijiang County, the proportion of rural labor transfer is about $80 \%$. As a result of the massive transfer of labor force, the biggest and key problem of Rural Revitalization is the talents. However, from the current research data, there is little relevant research on the issue of rural rejuvenation of talents in the old revolutionary areas of Sichuan. Therefore, it is particularly important to study the talent problem of Rural Revitalization in the old revolutionary areas of Sichuan.

\section{Analysis of the Reasons for the Lack of Talents in Vitalizing the Rural Areas in the Old Revolutionary Areas of Sichuan}

The lack of talents for Rural Revitalization in the old revolutionary areas of Sichuan is mainly due to two reasons: departure of local talents and little attraction for other places' talents to come.

\subsection{Analysis on the Causes of Local Talents Leaving}

In order to further clarify the reasons for the lack of talents in the old revolutionary areas of Sichuan, the research group interviewed the returning relatives in the old revolutionary areas of Sichuan from January to March 2019. Through interviews with rural transferees, we learn that the fundamental reason for reluctance to stay in rural areas is economic reasons. Most of the rural areas in the old revolutionary areas of Sichuan lack pillar industries, and the channels for farmers to increase their income are narrow, so they can only go out to work to increase their income. This massive brain drain further limits the development of the industry and forms a vicious circle. From the 30 villages sampled, only 4 villages have breeding and other related enterprises, which are difficult to operate because of the lack of talent. Moreover, relatively backward and short public service in rural areas is the second reason. In the old revolutionary areas of Sichuan, the shortage of public services such as heat supply, gas supply, culture, entertainment, excellent teachers and medical resources in the countryside, which make farmers prefer to spend money on urban housing rather than return to the countryside to live. Thirdly, with the improvement of people's living standard, their requirements for living environment are getting higher and higher, and they are more and more unwilling to return to the dirty and disorderly countryside. The population composition of the countryside has changed from old, weak, sick and disabled to old, sick and disabled.

\subsection{Analysis of the Reasons for the Weak Attraction of Talents from Other Areas}

The fundamental reason why talents from other places are unwilling to come is the weak attraction. For college student village officials, the current standard of village official subsidy implemented in the old revolutionary areas of Sichuan is 
still under the document of No. 52 of Sichuan Group Communication 2014. The monthly subsidy for graduate students is RMB2600 yuan, undergraduate students which is RMB2200 yuan, and the national areas are increased by RMB200 yuan respectively. Such wage standards are difficult to attract excellent village officials. In addition, the harsh environment in the old revolutionary areas of Sichuan has resulted in the leaving of many college student village officials.

\section{Countermeasure Analysis of Solving the Problem of Vitalizing Talents in the Old Revolutionary Areas of Sichuan Province}

Through investigation and analysis, it is found that the Rural Revitalization in the old revolutionary areas of Sichuan mainly lacks the following types of talents. First, the lack of talented people makes the Rural Revitalization in the old revolutionary areas of Sichuan lack of guides. Second, without enough new-type professional farmers, it leads to the inefficiency productivity of the rural revitalization industry development in that area. Third, the lack of investors results in weak vitality in these areas. In order to solve these kinds of problems, we must start with the needs of these talents. The demand for these talents has both generality and individuality. Therefore, this study puts forward countermeasures from two aspects: the common working environment and different personality needs of the talents.

\subsection{Setting up the Competitive Advantages Positively and Creating a Good Working Environment for Talents}

The old revolutionary areas in Sichuan are rich in ecological resources and have high forest coverage. We should build a good ecological environment of green water and hills according to our own advantages to enhance the attraction of talents. At the same time, we should fully explore the red resources of the old revolutionary areas in Sichuan, inherit the red genes-spirit of hard struggle and selfless dedication, and enhance the effectiveness of talents. Meanwhile, we should use unique local culture to unite the peasants, attract external investment to revive local culture, and give full play to its attraction of external resources and coordinate internal relations to enhance the cohesion of talents.

\subsection{Establishing and Improving the Talent Mechanism and Gathering Talents}

First, we should implement preferential policies to attract talents. The revitalization of the countryside is hard to be separated from the talented people who love the countryside. Talents can promote the revitalization of the countryside. However, due to the harsh natural conditions in the old revolutionary areas of Sichuan, the gap between urban and rural areas is large, and almost talents have left their homes to enter the city, resulting in the lack of pioneering spirit of the village officials and the scarce leadership in rural revitalization. To establish a 
leading team that understands agriculture, loves the countryside and loves the peasants, we should encourage migrant workers and businessmen to return home and startup businesses to promote rural development, and absorb the outstanding ones of these talents into the village Party branch and the village committee. Furthermore, we should steadily promote the new system of township talents, encourage retired cadres to return to their hometowns and serve. The system of ensuring economic treatment, political incentives and caring for village cadres is also needed to attract demobilization, veterans and local university graduates return hometown to start up business. Establish an incentive mechanism to select outstanding Party members from villages and towns to appoint them to the village Party branch and the village committee. Strengthen the selection of university student village officials, effectively solve the problems of college student village cadres such as non-practicality, lack of responsibility, desiring to leave, and non-proficiency. And ensure that university student village cadres who can work hard and move around can be selected, to play their due role and contribute to the Rural Revitalization and construction.

Secondly, scientific training should be carried out to cultivate new types of professional farmers. The development of agricultural industry needs new type of professional farmers, but many years of working economy destroyed the original labor structure, and the phenomenon of new type of professional farmers is rare, even in young and middle-aged people. The migrant workers not only yearn for the urban cultural living environment, but also suffer from economic and educational problems. However, through the investigation, it is learned that the main reason for this part of the transfer is economic problems. In order to solve the problem of insufficient new-type professional farmers, we should start from the key reasons of farmers' transfer. The basic step is that we should solve the problem of employment and income increase at home. It is necessary to strengthen agricultural vocational education and training to improve farmers' scientific and technological quality. So that they can gradually become the new force of modern agricultural development and new rural construction, and improve their income level.

Third, we should strengthen infrastructure construction, improve the level of public services and attract investors. The old revolutionary area in Sichuan is rich in tourism resources, local culture and mineral resources. But due to the inconvenience of transportation and other reasons, the resource advantages in this area have not been transformed into economic advantages. Therefore, in the process of Rural Revitalization in the old revolutionary areas of Sichuan, we must strengthen infrastructure construction such as transportation, network, the management and treatment of rural domestic waste, the rural environment, medical treatment, culture and sports. Beautiful environment, convenient transportation and high-quality public services will attract more people to invest in rural areas and solve the problems of funds and industries for rural revitalization. 


\section{Conclusion}

Starting from the lack of talents in the old revolutionary areas of Sichuan, this study puts forward some countermeasures to solve the problem of talents in the old revolutionary areas of Sichuan, which provides some ideas for solving the problem of talents in the old revolutionary areas of Sichuan. However, this study has not made a specific analysis of the reasons and countermeasures for the lack of talents in various districts and counties. Therefore, it is necessary to further integrate its own reality in solving the specific problems of vitalizing talents in various districts and counties in the old revolutionary areas of Sichuan.

\section{Funding}

Research and Innovation Team Project of Sichuan University of Arts and Sciences (No. 122 [2018] of Sichuan University of Arts and Sciences).

\section{Conflicts of Interest}

The author declares no conflicts of interest regarding the publication of this paper.

\section{References}

[1] Deng, L. (2019) The Core of Rural Revitalization in Western Minority Areas: Human. Journal of Central China Normal University, No. 1, 19-22.

[2] Liu, Z.Y. and Jiang, S. (2019) Urban Planning: Return of People in Vitalization of Rural Areas. Agricultural Economic Issues, No. 2, 43-52.

[3] Zhang, H.S. (2019) How to Keep People in Rural Areas: Some Thoughts on Promoting the Strategy of Vitalizing Rural Areas. Development, No. 1, 37-38.

[4] Ye, X.Q. (2019) Enlarging the Institutional Supply of Rural Revitalization around People. Farmers' Science and Technology Training, No. 1, 22-23.

[5] Zhang, G. (2018) The Key to Rural Revitalization: People. Zhejiang Economy, No. 7,61 . 